\title{
Bibliography of Finnish Population Research, 1973-1976
}

The bibliography covers the literature on population research published in Finland during 1973-76. The selection of these studies has been based on the same principles as in earlier bibliographies published every fourth year in this yearbook. Included are independent publications, articles in periodicals and statistics published in Finland. In general the bibliography excludes nonscientific articles in newspapers and weeklies as well as unpublished reports and academic theses. Also not included are studies presented at proceedings of conferences held in Finland if they were written abroad and treated subjects outside Finland. Coverage is less complete in peripherical fields.

In principle the main divisions appearing in the Population Index have been used with added subdivisions better suiting Finnish circumstances. Studies covering several fields of demography, which should rightly be listed in two or more divisions are included in only one division, i.e. in the division representing the primary field, on which the report is centered.

Lists of literature on population research have been published in Yearbooks II-IV of the Finnish Population and Family Welfare Federation and in volumes VI, IX, XI and XIII of the Yearbook of Population Research.

\section{A. GENERAL POPULATION STUDIES AND THEORY}

Herva, Aslak. The Regional optimal population points in Finland. Väestön- tutkimuksen vuosikirja - Yearbook of Population Research in Finland, XIV, Vammala 1976, pp. 95-102.

Kesäneuvokki. Demokraattisten asiantuntijoiden ja tutkijoiden kesäneuvokki 74. Väestö ja työvoima (Population and labour force). Joensuu 1974, $229 \mathrm{pp}$.

Krokfors, Christer. Geografi, befolkning och underutveckling. (Geography, population and underdevelopment). Terra 1974: 3, pp. 115-119.

Leppo, Kimmo. Väestön kokoa ja ikärakennetta säätelevät tekijät. (Factors regulating the size and the age structure of the population). Väestöbiologia, 1973, $20 \mathrm{pp}$.

Nieminen, Mauri-Markelin, Pasi. Suomen väestökirjanpito ja väkiluvun laskeminen. (Population counting and population registration). Tilastokeskuksen muistio n:o 27-Central Statistical Office, report n:o 27, 1974, $17 \mathrm{pp}$.

The Population of Finland. A World Population Year Monograph C. I. C. R. E. D SERIES. Published by the Central Statistical Office in cooperation with the Population Research Institute. Hämeenlinna 1974, $81 \mathrm{pp}$. Also Published in Finnish in Katsaus Suomen väestökehitykseen. Tilastokeskus. Tilastollisia tiedonantoja 54, 1975, $105 \mathrm{pp}$.

Population and development in Finland. Reply of Finland to the UN second inquiry on population and development. Väestöntutkimuslaitoksen julkaisuja A: 14. - Publications of Population Research Institute, Series A: 14, Helsinki 1973, $150 \mathrm{pp}$.

Sippola, Matti. Depopulation in development areas and its effect on the social 
environment and on development policy. The third Scandinavian demographic symposium 18-20 June in Tuusula, Finland. Scandinavian population studies 3 . The Scandinavian demographic society and in the Yearbook of population research in Finland XIII: Vammala 1974, pp. $95-100$.

Strömmer, Aarno. Väestönkehitys ja asuntopolitiikka. (Population development and housing policy). In laskeva syntyvyys - lamautuva yhteiskunta. Väestöliitto. Kolmikantasarja 5, Helsinki 1975, pp. $94-97$.

Tauriainen, Juhani. Maaseudulta muuttaminen ja sosiaalinen kohoaminen. (Rural outmigration and upward social mobility). Sosiaali- ja terveysministeriö. Sosiaalipoliittinen tutkimusosasto, julkaisu 1973: 4, Helsinki 1973, $48 \mathrm{pp}$. Also in Sosiaalinen aikakauskirja 1973: 4, pp. $402-411$.

Tauriainen, Juhani. Maaseudun väestökato ja maaseudun rakenteelliset muutokset. (Rural depopulation and rural structural changes.) Sosiaali- ja terveysministeriö. Sosiaalipoliittinen tutkimusosasto, julkaisu 1973: 1, $175 \mathrm{pp}$.

Tauriainen, Juhani-Koivula, Samuli. Maaseudun väestökatoalueiden olot ja ongelmat. (Social problems and conditions in rural depopulation areas.) Suomen itsenäisyyden juhlavuoden 1967 rahasto. Sarja B: 9, Helsinki 1973, pp. 157. Also in Sosiaalinen aikakauskirja 1973: 2, pp. $158-168$.

Tauriainen, Juhani-Koivula, Samuli. The conditions and problems of rural depopulation areas. SVT. Sosiaalisia erikoistutkimuksia XXXII: 33 - Official Statistics of Finland, Special social studies XXXII: 33, 1973, 162 pp.

Valkonen, Tapani. Suomen viimeaikainen väestönkehitys ja väestöongelmat. (Recent Population Development and Population Problems in Finland). Helsingin Kauppakorkeakoulu. Sosiologisia tutkimuksia 8, Helsinki 1974, 15 pp.

Varsinais-Suomen seutukaavaliitto. Väestö- ja työpaikkatavoitteet. (Planning figures for population and employment.) Turku 1974.

\section{B. REGIONAL POPULATION STUDIES}

Alanen, Leena. Laatokankarjalaiset toisen maailmansodan jälkeen. Sosiologinen tutkimus laatokankarjalaisen siirtoväen alueellisesta ja ammatillisesta uudelleensijoittumisesta sekä väestörakenteesta. (The Laatokka-Karelian population after the Second World War. A sociologial study of the regional and occupational resettlement and population structure of Laatokka-Karelian migrants.) Joensuun korkeakoulu. Karjalan tutkimuslaitos. Julkaisu 11. Joensuu 1975, $111 \mathrm{pp}$.

Asp, Erkki-Rantanen, Kari. Suomen saamelaiset vuonna 1970 . Suomen saamelaiset vuoden 1970 väestölaskennan ennakkotietojen valossa. (Lapps in Finland 1970). Turun yliopiston sosiologian laitos, moniste 66, 1973, $36 \mathrm{pp}$.

Eriksson, Aldur W., et al. Population studies on the Alland Islands. In 2 parts. Human Heredity (Basel), Vol. 23. Nos. 5 and 6. 1973. Part 1. Prediction of kinship from migration and isolation by distance. No 5, pp. 422-433. Part 2. Historical population structure: inference from bioassay of kinship and migration. No 6 , pp. $511-534$.

Etelä-Savon seutukaavaliitto. EteläSavon väestörakenne 1973-2000. (The population structure of Etelä-Savo in 1973-2000.) Yhteenveto Etelä-Savon seutukaavaliiton väestösuunnitteiden edellyttämästä ikä- ja sukupuolirakennekehityksestä v. 1973-2000. Mikkeli 1975.

Etelä-Savon seutukaavaliitto. EteläSavon väestö- ja työpaikkalaskelmat v. $1950-85$. (Population and employment in southern Savo in 1950-85.) 1974: 18, Mikkeli 1974.

Forsberg, Karl-Erik. Finlandssvenskarna 1970 enligt folkräkningen. (The Swedish speaking population in Finland according to the 1970 Census.) Reprinted from Svenskbygd no 3/1973, 6/1973, 7/ 1973 and 5/1974, 32 pp. Also Svenska Befolkningsförbundet i Finland, publication no 17. 1975, 56 pp.

Frederiksen, Ilkka. Oulun läänin työvoimareservi. (The Labor Force Reserves 
in the Province of Oulu.) Oulun lääninhallitus. Suunnittelujaosto. Julkaisu 10, Oulu 1973, 68 pp.

Helsingin kaupunkisuunnitteluvirasto. Selvitys väestökadosta vuosina 19701974. (Report on depopulation in the years 1970-1974.) Yleiskaavaosaston julkaisu 4 A 7/1975. Helsinki 1975.

Helsingin seutukaavaliitto. Seutukaavoituksen seuranta 1973, väestö ja työpaikat. (Population and employment). Helsinki 1974.

Helsingin taloussuunnittelutoimikunta. Osa-alueittainen ikärakenne-ennuste. Ennustemenetelmän selostus. (Age structure forecast for districts.) Helsingin kaupunkisuunnitteluvirasto - Helsingin tietokeskus. Helsinki 1974.

Huotari, Voitto. Suomen ortodoksinen väestö. (The Orthodox population in Finland.) Helsingin yliopiston käytännöllisen teologian laitos. Kirkkososiologian julkaisuja A 1. 1975, 160 pp.

Hämeen läänin- ja piirihallintoviranomaisten neuvottelukunta. Suunnittelujaosto. Hämeen läänin väkiluvun kehitys kunnittain 1960-1972 vallinneen ja vuoden 1973 kuntajaotuksen mukaisena. (Population trends in the Province of Häme by municipalities in 1960-1972 according to the municipality division then prevailing and that of 1973.) Moniste 9. Hämeenlinna 1974, $69 \mathrm{pp}$.

Järvikoski, Timo. Kemihaaran allasalueen väestötutkimus. (A study of the population of the Kemihaara basin region.) Vesihallitus. Tiedotus 83 . Helsinki 1975, 64 pp.

Kanta-Hämeen seutukaavaliitto. Seutukaavoituksen seurantajärjestelmä: Kanta-Hämeen väestö ja työpaikat (Population and emplyment in Kanta-Häme). Julkaisu 1974 II: 64. Hämeenlinna 1974.

Kaukiainen, Y. Miksi kansa lisääntyi. (Why the population grew.). Historiallinen Aikakauskirja 1973: 2 .

Keski-Suomen lääninhallitus. Suunnittelujaosto. Keski-Suomen väestönkehityksestä äänestysalueittain vuosina 1960-1970. (Population development in Keski-Suomi according to voting districts in 1960-1970). Julkaisu 5. Jyväskylä 1973, $41 \mathrm{pp}$.
Keski-Suomen seutukaavaliitto. Seuranta 73: Keski-Suomen väestön ja työpaikkojen kehitys vuosina $1950-2000$. (The development of population and jobs in Central Finland in 1950-2000.) Julkaisu B: 26. Jyväskylä 1974, 102 pp.

Koivukangas, Olavi. Finns in America - as viewed from Finland. A presentation at the Finnfest Bicentennial seminar, Hancock, Michigan, July 30th, 1976. Siirtolaisuus - Migration 1976:3, $9 \mathrm{pp}$.

Kuopion kaupunkisuunnittelutoimikunta. Väestölaskelmia. Vertaileva selvitys. (Population prospects. A comparative study.) Erillistutkimukset 5. Kuopio 1973, $38 \mathrm{pp}$.

Kymen lääninhallitus. Väestönmuutokset Kymen läänissä 1961-1974. (Population changes in the Province of Kymi in 1961-1974). Kouvola 1975, 132 pp.

Kymenlaakson seutukaavaliitto. Väestö- ja työpaikkaselvitys 1975. (Report on population and employment in 1975.) Julkaisu B 42. Karhula 1975, 100 pp.

Lankinen, Markku. Miksi Helsingin väestö vähenee? (Why does the population of Helsinki decrease?) Helsingin kaupunkisuunnitteluvirasto. Toiminnallisia selvityksiä 24 , Helsinki 1973,85 pp.

Lankinen, Markku. Selvitys Itä-keskuksen ja sen ympäristön väestön kehityksestä. (A report on the population development of the East-Center of Helsinki and its surroundings.) Itä-keskusprojekti, Helsinki 1975.

Lankinen, M. Haaga-Vantaa, osaalueittaiset väestöennusteet vuoteen 1990 . (A population forecast for Haaga-Vantaa up to 1990.) Helsingin rakentamisohjelmatoimikunta, Haaga-Vantaa -projekti. Helsinki 1976.

Lapin seutukaavaliitto. Lapin läänin väestö- ja työvoima $1960-2000$. (The population and the labor force of the province of Lappland in 1960-2000.) Julkaisu A 2, Rovaniemi 1974.

MaTaPuPu-alueen väestöselvitys. Väestön määrä ja ikärakenne 31. 12. 1972, 1975, 1980 ja 1985. (Population size and age structure $31.12 .1972,1975,1980$ ja 1985.) MaTaPuPu -projekti: Helsingin tietokeskus ym. Helsinki 1975.

Mikkola, Kimmo. Ruotsissa vuosina 
1946-1970 ansiotyössä ollut suomalaisväestö. (Finns employed in Sweden in 1946-1970.) Tilastokeskuksen tutkimuksia 25 - Central Statistical Office Studies 25. Helsinki 1973, 40 pp.

Mustonen, Irmeli. Muuttavan väestön koulutusrakenne Helsingin seutukaavaliiton alueella. (The educational structure of migrants in the Helsinki area.) Helsingin seutukaavaliitto, Helsinki 1973, $109 \mathrm{pp}$.

Nykänen, Heikki, Etelä-Savon väestö ja työvoima v. 1950-1985. (The population and the labor force of southern Savo 1950-1985.) Etelä-Savon Seutukaavaliitto. Julkaisu 1973: 5, Mikkeli.

Pesonen, Jukka. Ruokakunnat Tampereella 1950,1960 ja 1970 väestölaskentojen mukaan. (Households in Tampere according to the 1950, 1960 and 1970 Census.) Tilastollisia tiedonantoja Tampereelta $1974: 4$, pp. 92-100.

Päijät-Hämeen seutukaavaliitto. Muuttoliike Päijät-Hämeen maalaiskunnissa vuonna 1974. (Migration in the rural municipalities of Päijät-Häme in 1974.) Julkaisu 1, 1976.

Raivio, Yrjö. Kanadan suomalaisten historia I. (A History of Canadian Finns I.) Kanảda $1975,529 \mathrm{pp}$.

Sarin, Mirja. Pendelöivä väestö Helsingissä, Espoossa ja Vantaalla. (Commuting in Helsinki, Espoo and Vantaa.) Tilastollisia kuukausitietoja Helsingistä - Statistical monthly review of Helsinki 1974: 4, pp. 165-172. English summary.

Sarin, Mirja. Väestön demografinen ja alueellinen rakenne Helsingissä vuonna 1970. (The demographic and regional structure of the population in Helsinki in 1970.) Tilastollisia kuukausitietoja Helsingistä - Statistical monthly review of Helsinki 1975: 7, pp. 201-242. English summary.

Savaspuro, T. Vantaan väestö- ja ikärakenne-ennuste 01.01.1976-1982. (Population and age structure forecast.) 1976.

Suomen asutus 1560-luvulla. Kyläluettelot. (Settlement in Finland in the 1560 s.) Helsingin yliopiston historian laitoksen julkaisuja 4. Helsinki 1973, 259 pp.

Tikkanen, Anja. Lapin evakot. (Evac- uated people from Lappland.) Hämeenlinna 1975, $304 \mathrm{pp}$.

Tilastokeskus ja Satakunnan seutukaavaliitto. Satakunnan väestö 1970. Väestölaskenta. (The population of Satakunta 1970). Julkaisu A: 75, 1973.

Toukomaa, Pertti. Finnarna i Sverige. (Finns in Sweden.) Finsk Tidskrift 1975: 9-10, pp. $457-467$.

Valkonen, Tapani. Economic development and regional population distribution: A comparative study of Finland, Norway, Sweden and Wisconsin 1900 1970. Research Group for Comparative Sociology. University of Helsinki. Research reports no 7. 1975, 48 pp.

Varsinais-Suomen seutukaavaliitto. Loimaan seudun työvoimareservi 1973. (The labor force reserve of the Loimaa region in 1973.) Turku 1973.

Varsinais-Suomen seutukaavaliitto. Väestö- ja työpaikkatavoitteet. (Population and employment goals.) Turku 1974.

Wickström, Johan. Befolkningen under ett halvt sekel i sydvästra Finlands skärgård. (The population of the southeastern archipelago of Finland during half a century.) Skärgård i omvandling (utg. av Nordenskjöldssamfundet 1974).

Witthauer, $K$. Bevölkerungsabnahme in Norden Finlands. (Depopulation in northern Finland.) Petermanns Geographische Mitteilungen (Gotha) 119(2): 139-140, 1975.

Uudenmaan seutukaavaliitot. Uusimaa. Väestö ja työvoima $1960-1985$. (The Population and labor force of the province of Uusimaa in 1960-1985.) Helsinki 1975, $117 \mathrm{pp}$.

\section{SPATIAL DISTRIBUTION}

Forsberg, Karl-Erik-Härkäpää, Markus. Asumisväljyysennuste 1980 ja 1985. (A forecast of living space per person in 1980 and 1985.) Tilastollisia kuukausitietoja Helsingistä - Statistical monthly review of Helsinki 1976:5, pp. 141-157. English summary.

Järvenranta, Marjut. Äärimmäisen ahtaasti asuvat ruokakunnat Suomessa vuonna 1970. (Households living in ex- 
tremely overcrowded conditions.) Sosiaalinen aikakauskirja 1973: 3, pp. 259-279.

Kuokkanen, Aarne. Asuminen ja asukkaat Tampereella vuosien $1973-74$ vaihteessa osa-aluejaon mukaan. (Housing and the inhabitants of Tampere at the end of 1973 according to municipal districts.) Tilastollisia tiedonantoja Tampereelta $1974: 4$, pp. $107-113$.

Pajulahti, Lauri. Kuopion läänin eläkeikäisten asunto-olot. (The housing conditions of pensioners in the province of Kuopio.) Kuopion lääninhallitus, 1974. $146 \mathrm{pp}$.

Tukiainen-Pankakoski, Tuuli. Ahtaasti asumisen levinneisyys Suomessa vuonna 1970. (The extension of overcrowded housing in Finland in 1970.) Helsingin yliopiston sosiaalipolitiikan laitos. Tutkimus 1975: 1, 289 pp.

\section{TRENDS IN POPULATION SIZE}

Espoon kaupunginkanslia. Espoon väestösuunnite $1975-86$. (The planning figure for the population of Espoo in 1975-86.) Espoo 1975.

Espoon kaupunginkanslia. Väestösuunnite vv. 1976-86. (The planning figure for the population of Espoo in 1976-86.) Espoo 1976.

Etelä-Karjalan seutukaavaliitto. Taloudellis-demografinen väestö- ja työpaikkaennustejärjestelmä. (An economicdemographic forecast system for population and employment.) Julkaisu 1975:2. Lappeenranta.

Etelä-Savon seutukaavaliitto. EteläSavon keskukset ja vaikutus-alueet 1972 ja 1985. (The centers and areas of influence in Etelä-Savo in 1972 and 1985.) Julkaisu 6, Mikkeli 1973, 46 pp.

Forsberg, Karl-Erik. Befolkningsprognos för finlandssvenskar. 1. Folkmängden. (A forecast of the Swedish speaking population in Finland.) Helsingfors regionplaneförbund. Helsinki 1975.

Fougstedt, Gunnar. Agronomikunnan rakenne ja sen vastaista kehitystä kuvaava ennuste. (The structure of Finland's agronomists and prospects for its future development.) Agronomien yhdistys, julkaisu 80. Forssa 1974, 16 pp.

Hulkko, Jouko. Suomen väestönkehitys verrattuna muiden Euroopan valtioiden väestönkehitykseen. (Finnish population development compared with population development in other European countries.) Laskeva syntyvyys - lamautuva yhteiskunta. Väestöliitto. Kolmikanta sarja 5. Helsinki 1975, pp. 20-41.

Itä-Uudenmaan seutukaavaliitto. Seuranta 1973: Itä-Uudenmaan väestö ja työvoima 1950-2000. (The population and the labor force of Eastern Uusimaa 1950-2000. Porvoo 1974, 48 pp.

Karjalainen, Irma. Syntyvyyteen, kuolleisuuteen ja nettomuuttaneisuuteen perustuva kunnittainen ennakointi väestönkehityksestä Keski-Pohjanmaan kunnissa. (A population forecast for the municipalities of Keski-Pohjanmaa based on fertility, mortality and net-migration.) Pohjalaisten osakuntien aluetutkimustoimikunta, julkaisu B: 18. Tampere 1974.

Kenttä, Aaro. Suomen väestönkehityksen näköalat. (Prospects of population trends in Finland.) KOP kuukausikatsaus 1975: 10, pp. 1-12.

Kenttä, Aaro. Suomen väestönkehityksen vaihtoehtoja. (Alternative population trends in Finland.) Laskeva syntyvyys - lamautuva yhteiskunta. Väestöliitto. Kolmikantasarja 5. Helsinki 1975, pp. $54-69$.

Kymenlaakson seutukaavaliitto. Seurantajärjestelmä 1973. Osa 1. Väestöennusteet. (Population forecast.) Julkaisu B: 34, Karhula 1973, 15 pp.

Nieminen, Mauri. The development of Finland's population in 1950-1970. Bank of Finland. Monthly bulletin 1973: 1, pp. $20-27$.

Nieminen, Mauri. Väestönkehitys suuralueittain vuosina 1950-1980. (Population trends by economic areas in 19501980.) KOP kuukausikatsaus 1973: B 17, pp. $1-30$.

Nykänen, Heikki. Etelä-Savon väestö ja työvoima $1950-1985$. (The population and the labor force of Southern Savo in 1950-1985.) Etelä-Savon seutukaavaliiton julkaisu 5, Mikkeli 1973, 36 pp.

Seppänen, Jaakko. Työvoiman tarjonta 
ja työpaikkatavoitteet Keski-Suomen läänissä vuoteen 1980 mennessä. (The labor force supply and the employment goals of the province of Central Finland until 1980.) Työvoimaministeriö. Suunnitteluosasto. Monistettuja tutkimuksia 7 . 1974, $113 \mathrm{pp}$.

Taloudellinen suunnittelukeskus. Suomen väestön ja työvoiman kehityspiirteitä vuoteen 2000. (Features of population and labor force trends in Finland until the year 2000.) Helsinki 1974, 76 pp.

Tilastokeskus. Katsaus Suomen väestönkehitykseen. (A survey of Finnish population trends.) Tilastollisia tiedonantoja 54 - Central Statistical Office. Statistical surveys 54. Helsinki 1975, 105 pp.

Tilastokeskus. Laskelmia tulevasta väestönkehityksestä $1972-2000$. Kunnittainen ennuste 1973. (Population trends in $1972-2000$. A forecast by municipalities.) Tilastotiedotus VÄ 1973:6 - Statistical Central Office. Statistical reports VA 1973:6, 61 pp.

Tilastokeskus. Väestöennusteet 19732000. Koko maan väestöennusteet ja alueellisten laskelmien vertailu. (Population projections for 1973-2000. Population projections for the whole country and a comparison of regional calculations.) Tilastollisia tiedonantoja $52-$ Central Statistical Office, Statistical surveys 52 . Helsinki 1974, 69 pp.

Työvoimaministeriö. Työvoiman tarjonnan kehitys vuoteen 1980 . (The labor force supply until 1980.) Monistettuja tutkimuksia 6, 1973, $63 \mathrm{pp}$.

Valtioneuvoston kanslia. Suunnitteluosasto. Käytettävissä olevien työvoimavarojen kehitys vuoteen 1990. (The development of available manpower up to 1990.) Julkaisu 1975: 10, 91 pp.

Valtioneuvoston kanslia. Suunnitteluosasto. Lääneittäinen työpaikka- ja väestösuunnite vuosille 1980 ja 1985. (Planning figures for population and employment for 1980 and 1985.) Julkaisu 1975: 9, $204 \mathrm{pp}$.

Valtioneuvoston kanslia, Helsingin seutukaavaliitto, Pääkaupunkiseudun yhteistyövaltuuskunta. Helsingin seudun kasvutekijätutkimus (Kaste-tutkimus), 3. väliraportti, Helsingin seudun kehityksen ennakointi. (A forecast concerning the development of the Helsinki area.) Helsinki 1976, $78 \mathrm{pp}$.

\section{E. MORTALITY}

Amnell, Gustav. Mortalitet och kronisk morbiditet i barnåldern. En kohortundersökning av år 1955 födda Helsingforsbarn. (Mortality and chronic morbidity in childhood. A cohort investigation of children born in 1955 in Helsinki.) Forssa 1974. $133 \mathrm{pp}$.

Brummer, Pekka. Kuolleisuuden kehitys maassamme sadan viime vuoden aikana. (Mortality trends in Finland during the last hundred years.) Suomen Lääkärilehti 1976: 19 .

Hemminski, E. Demographic effects of the elimination of selected causes of death in Finland. Duodecim 90 (17): 1167 -1179. 1974.

Hemminski, E. Yleisimpien kuolemansyiden vaikutus suomalaisen väestön elinvuosiin. (The life expectancy of the population and the influence of the most common causes of death.) Duodecim 90 (17): 1167-1179. 1974

Hulkko, $S$. Tampereen perinataalikuolleisuus 1955-69. (Perinatal mortality in the city of Tampere in 19531969). Duodecim 89: 240-246. 1973. English summary.

Huuhtanen, A. Sudden and unexpected deaths in infancy. Duodecim 90 (19): 1295-1302. 1974.

Kolari, Risto. Kuolleisuus. Kuolleisuuden alueellinen jakautuminen Suomessa 1961-1972. (Mortality: the regional distribution of mortality in Finland in 1961 -1972) Tilastokeskus. Tutkimus 33 Central Statistical Office. Studies 33 Helsinki 1975, 95 pp.

Komiteanmietintö 1974: 66. Itsemurhatoimikunnan mietintö. (The report of the Suicide Committee.) Helsinki 1974, $103 \mathrm{pp}$.

Lähderanta, Uolevi. Helsinkiläisten kuolemaan johtaneet kotitapaturmat. Ko- 
titapaturmissa loukkaantuneiden ja kuolleiden helsinkiläisten vertailu vuosina 1963-65. (Fatal accidents occurring in the home among Helsinki residents in 1963-65 and a comparison of the injured and the dead in accidents occurring in the home.) Tilastollisia kuukausitietoja Helsingistä - Statistical monthly review of Helsinki 1973:5, pp. 159172. English summary.

Lähderanta, Uolevi - Karjalainen, Pirkko. Suomessa vuosina 1960-1969 kodin piirissä tapaturmaisesti hukkuneet. (Fatal drowning events at home in Finland in 1960-1969.) Sosiaalinen aikakauskirja 1975: 1, pp. 71-79.

Lähteinen, Martti. Työtapaturmalukujen kehitys vuosina $1960-72$ sekä vuoden 1970 työtapaturmien yksityiskohtaisempaa tarkastelua. (Industrial accidents during 1960-72 and a detailed examination of industrial accidents in 1970.) Sosiaalinen aikakauskirja 1974: $2-3$, pp. 144-147. English summary. Mustonen, Maija - Suominen, Risto Suonoja, Kyösti. Imeväiskuolleisuuteen vaikuttavat sosiaaliset ja taloudelliset tekijät Suomessa 1910-1971. (Socia] and economic factors influencing infant mortality in Finland between 1910 and 1971.) SVT Sosiaalisia erikoistutkimuksia XXXII:46 - Official Statistics of Finland. Special social studies XXXII: 46, 1976, 148 pp. English summary.

Rapola, J. Åkillinen imeväiskuolema eli SIDS. (Sudden infant death syndrome, SIDS). Duodecim 90 (19): 12761279. 1974.

Rissanen, Viljo et.al. Deaths from ischemic heart disease in Helsinki in 1959-1968: vital statistics and medicolegally autopsied sudden deaths. Acta Medica Scandinavica. 197(1-2): 43-50. Stockholm 1975.

Rissanen, Viljo et.al. Deaths from ischemic heart disease in persons aged 65 or younger in Helsinki in 1970: with special reference to pathoanatomic, findings in hearts. Acta Medica Scandinavica $197(1-2)$ : $51-60$. Stockholm 1975.

Saxén, Åke. Kuolleisuus Helsingissä 1960-luvulla. (Mortality in Helsinki dur- ing the 1960s). Tilastollisia kuukausitietoja Helsingistä - Statistical monthly review of Helsinki, $1975: 1$, pp. 3-16. English Summary.

Turpeinen, Oiva. Regional differentials in Finnish mortality rates. Scandinavian Economic History Review (Copenhagen) 21 (2): 145-163. 1973.

Valkonen, Tapani. Elintaso, kaupungistuminen ja alueelliset kuolleisuuserot Suomessa, Ruotsissa ja Norjassa. (The standard of living, urbanization and the regional variation of mortality in Finland, Sweden and Norway.) Helsingin yliopiston sosiologian laitoksen tutkimuksia 204. 1975, 154 pp.

Valkonen, Tapani. Suomen alueellisten kuolleisuuserojen syistä. (On the causes of regional differences in mortality in Finland.) Sosiologia 1975: 12, pp. 175-185.

Aikäs, Timo. Kuolemantapaukset työja matkatapaturmissa vuonna 1972. (Fatal accidents at work and coming to and from work in 1972.) SVT Sosiaalisia erikoistutkimuksia XXXII: 42 - Official Statistics of Finland. Special Social Studies XXXII: 42, 1975, 117 p.

Aikäs, Timo. Työ- ja työmatkatapaturmien kuolemantapaukset vuonna 1972. (Fatal accidents at work and coming to and from work in 1972.) Sosiaalinen aikakauskirja $1975: 3, \quad$ pp. $\quad 230-235$. English summary.

\section{F. FERTILITY AND NATURAL INCREASE}

Eriksson, Aldur. Human twinning in and around the Alland Islands. Skrifter utgivna av Ålands kulturstiftelse VIII. Mariehamn 1973, $159 \mathrm{pp}$.

Forsberg, Karl-Erik. Helsingissä 31.12. 1970 asuneiden naisten hedelmällisyys. (The fertility of women resident in Helsinki on 31.12.1970.) Tilastollisia kuukausitietoja Helsingistä - Statistical monthly review of Helsinki 1976: 7, pp. 265-275. English summary. 
Kallio, Hanna. The Finnish abortion and sterilization situation and family planning guidance according to the Public Health Act. Väestöntutkimuksen vuosikirja - Yearbook of Population Research in Finland XIII. Vammala 1974, pp. $170-173$.

Koskelainen, Osmo - Leppo Kimmo Sievers, Kai. Pohjois-suomalaisten nuorten miesten seksuaalisesta käyttäytymisestä. (The sexual behavior of young men in Northern Finland.) Väestöntutkimuslaitoksen julkaisuja, sarja B 32 Publications of Population Research Institute, series B: 32 . Helsinki 1973, 175 pp.

Kotiranta, Maija-Liisa. Aborttipyynnön sosiaaliset perusteet. (Social motives for demanding abortions.) Väestöntutkimuslaitoksen julkaisuja, sarja B: 39 - Publications of Population Research Institute, series B: 39 . Helsinki 1975, 110 pp.

Lahti, Raimo. The effects of new abortion and sterilization laws in our country. Suomen lääkärilehti 1973: 5 .

Leppo, Kimmo - Koskelainen, OsmoSievers, Kai. Contraceptive Practices in Finland in 1971. Väestöntutkimuksen vuosikirja - Yearbook of Population Research in Finland XIII, Vammala 1974, pp. $47-60$.

Lindgren, Jarl. Fertility trends in Finland. Väestöntutkimuksen vuosikirja - Yearbook of Population Research in Finland XIV. Vammala 1976, pp. 6984.

Lindgren, Jarl. Legislation directly and indirectly influencing fertility in Finland. Väestöntutkimuslaitoksen julkaisuja, sarja B: 31 , Publications of Population Research Institute, series B: 31 . Helsinki 1973, $42 \mathrm{pp}$.

Lindgren, Jarl. Suomalaisen syntyvyyden kehityskuva. (Features of Finnish fertility trends.) Väestöntutkimuslaitoksen julkaisuja, sarja B:38. Publications of the Population Research Institute, series B: 38, Helsinki 1975, 141 pp.

Lindgren, Jarl. Vuoden 1974 syntyvyyden kasvu. (Growth of fertility in 1974.) Väestöntutkimuslaitoksen julkaisuja, sarja D: 2 - Publications of Population Research Institute, series D: 2. Helsinki 1976, 17 pp. Also in Laskeva syntyvyys
- lamautuva yhteiskunta. Väestöliitto, Kolmikantasarja 5, Helsinki 1975, pp. 106-117.

Myrskylä, Pekka. Syntyvyys: syntyvyyden kehitys ja alueelliset erot Suomessa. (Fertility development and regional differences in fertility in Finland.) Tilastokeskus. Tutkimus $36-$ Central Statistical Office. Studies 36. Helsinki 1976, 114 pp.

Puntala, Pentti. Sterilisaatio ja väestöongelmat. (Sterilization and population problems.) Suomen lääkärilehti 1973: 26.

Turpeinen, Oiva. Fertilitetens årliga fluktuationer och familjeplanering i Finland under den förindustriella tiden. (Annual fluctuations of fertility and family planning during the preindustrial period in Finland.) Historisk Tidsskrift för Finland 1976: 3 .

Ylppö, Arvo. Aborttilaki ja syntyvyys (The abortion act and fertility.) Suomen lääkärilehti 1973: 10.

\section{G. MARRIAGE, DIVORCE AND THE FAMILY}

Lietsala, Leena. Avioliiton ulkopuolella syntyneiden lasten vanhemmat. 1. osa: Isät ja elatusvelvolliset. (Fathers and persons liable to support children born out of wedlock.) Tilastollisia kuukausitietoja Helsingistä - Statistical monthly review of Helsinki 1973: 12, pp. 395-426. English summary.

Lietsala, Leena. Avioliiton ulkopuolella syntyneiden lasten vanhemmat. 2. osa: Aidit (Mothers of children born out of wedlock.) Tilastollisia kuukausitietoja Helsingistä - Statistical monthly review of Helsinki 1974: 7-8, pp. 263-318. English summary.

Ritamies, Marketta-Visuri, Elina. Finnish family size - accidental or planned. Väestöntutkimuksen vuosikirja - Yearbook of Population Research in Finland, XIV. Vammala 1976, pp. 57-68.

Ritamies, Marketta-Visuri, Elina. Suomalaisten perhekoko - sattuma vai suunnitelma. (Finnish family size - ac- 
cidental or planned.) Väestöntutkimuslaitoksen julkaisuja, sarja D: 1 - Publications of Population Research Institute, series D: 1. Helsinki 1975, $186 \mathrm{pp}$.

Sihvo, Jouko. Avioliitto ja avioero. (Marriage and divorce.) Kirkon tutkimuslaitos. Sarja A: 30, 1976, 153 pp.

Tauriainen, Juhani. Perheiden olot ja ongelmat maaseudun väestökatoalueilla. (Family conditions and problems in rural depopulation areas.) Sosiaali- ja terveysministeriö. Sosiaalipoliittinen tutkimusosasto. Tutkimuksia 1973:2, $237 \mathrm{pp}$.

Visuri, Elina. Suomalaisten perhekoko - sattuma vai suunnitelma. (Finnish family size-accidental or planned.) In Laskeva syntyvyys - lamautuva yhteiskunta. Väestöliitto. Kolmikantasarja 5. Helsinki 1975. pp. $42-53$.

\section{H. INTERNATIONAL MIGRATION}

Bergman, Turo. Maastamuutto ja työvoimapolitiikka. Tutkimus työvoiman Ruotsiin muuton yksilöllisistä ja yhteiskunnallisista syy-yhteyksistä. (Emigration and labour force policy. A study of the individual and social nexus at migration to Sweden.) Työväen taloudellinen tutkimuslaitos. Tutkimuksia 1974: 1. Helsinki $1974,49 \mathrm{pp}$.

Bergman, Turo. Suomalaisten muuttoliike Ruotsiin. Selvitys muuttoliikkeen syistä ja siitä aiheutuvista ongelmista. (Migration to Sweden. A study on the causes of migration and the problems produced by migration.) Työväen taloudellinen tutkimuslaitos Katsaus 1974:1, pp. $1-17$.

Edgren, Christian. Suomalaisen siirtolaistyövoiman rakenne ja taloudellinen asema Ruotsissa. (The structure of the Finnish emigrants in Sweden and their economic status.) Elinkeinoelämän tutkimuslaitos. Tutkimus B: 3. Helsinki 1975, $204 \mathrm{pp}$.

Edgren, Christian-Wiman, Ronald. The structure of time-lags between the decision and the start of migration. Migration research in Scandinavia. Proceedings of the Nordic seminar on mi- gration research held at Siikaranta, Finland, on January 3-5, 1973. Ministry of labour, Planning division. Migration reports 4, Helsinki 1973, pp. 208-220.

Edgren, Christian-Wiman, Ronald. Suomalainen siirtolaistyövoima Ruotsissa vuonna 1972. (The Finnish emigrants in the Swedish labour force.) Elinkeinoelämän tutkimuslaitos. Tutkimuksia C 3 . Helsinki 1973. $119 \mathrm{pp}$.

The Finnish experience in the Western Great Lake Region. New perspectives. Ed by Karni, Michael-Kaups, Matti - Ollila, Douglas J., Jr. Institute for Migration. Migration studies C 3. Turku 1975, 232 pp.

Gustafsson, Mervi. Euroopan talousyhteisön siirtotyövoima. (The emigrants in the labor force of the EEC.) Tampereen yliopiston politiikan laitoksen tutkimuksia n:o 36. Tampere 1974, $176 \mathrm{pp}$.

Heikkinen, Sirkka-Liisa. Ruotsista palanneet. Vuosina 1968-69 ja 1971 Ruotsista Suomeen palanneita koskeva tutkimus. (Returnees from Sweden in 196869 and 1971.) Työvoimaministeriö. Suunnitteluosasto. Siirtolaisuustutkimuksia 5 . Helsinki 1974, 74 pp.

Huhtanen, Pekka. Muuttajan muotokuva ja sopeutuminen. (The portrait of the migrant and how he has adjusted.) Työvoimaministeriö. Suunnitteluosasto. Monistettuja tutkimuksia n:o 11, 1975, $230 \mathrm{pp}$.

Jungar, Sune. Från Åbo till Ryssland. En studie i urban befolkningsrörlighet 1850-1890. (From Turku to Russia. A study of urban population mobility in 1850-1890). Acta Academiae Aboensis A 47: 3. Åbo 1974.

Järvenpää, Pentti. Suomalaiset menestyvät Torontossa. (Finns succesful in Toronto.) Siirtolaisuus - Migration 1976: 1, pp. $18-27$.

Kero, Reino. Migration from Finland to North America in the years between the United States Civil War and the First World War. Annales Universitatis Turkuensis Ser. B. Vammala 1974. 260 pp. Also in Migration Studies. Institute for migration. Series C 1. Turku 1974, 260 pp.

Kero, Reino. The migration of Finns from North America to Soviet Karelia in 
the early 1930s. Institute for Migration. Migration studies C: 3 . Helsinki 1975, $12 \mathrm{pp}$.

Koivukangas, Olavi. Kansainvälistä yhteistyötä siirtolaistutkimuksessa. (International cooperation in the field of emigration research.) Siirtolaisuus - Migration. 1975: 1, pp. 4-7.

Koivukangas, Olavi. Scandinavian immigration and settlement in Australia before World War II. Institute for Migration. Migration studies 62. Kokkola 1974, $333 \mathrm{pp}$.

Koivukangas, Olavi. Suomalainen siirtolaisuus Australiaan. (Finnish emigration to Australia.) In Juhani Lompolo, Maa johon mahtuu. Jyväskylä 1973. pp. 157-173.

Koivukangas, Olavi. Suomalainen siirtolaisuus Australiaan toisen maailmansodan jälkeen. (Finnish migration to Australia since World War II.) Institute for Migration. Migration studies A: 1 . Kokkola 1975, 262 pp.

Majava, Altti. Joint Project on Emigrant Workers, Sections 1.2, 5.2, 5.3, 7.2, 7.3., National Report on Finland OECD/ $\mathrm{CT} / \mathrm{AC} / \mathrm{MIC} / 30$, Ministry of Labour, Helsinki 1975.

Majava, Altti. Migration between Finland and Sweden from 1946 to 1974. A demographic analysis. Preliminary report. Ministry of Labour. Planning Division. Helsinki 1975, $98 \mathrm{pp}$.

Majava, Altti. Migration from and to Finland in 1974. The third SOPEMI Report. Ministry of Labour, Helsinki 1974. $19 \mathrm{pp}$.

Majava, Altti. Migration from and to Finland in 1975. The fourth SOPEMI Report. Ministry of Labour, Helsinki 1976, $20 \mathrm{pp}$.

Majava, Altti. Pohjoismaiden välinen muuttoliike 1951-1973. (Migration between Nordic countries in 1951-1973.) Siirtolaisuus - Migration 1975: 1, pp. $22-25$.

Mikkola, Kimmo. Return Migration from Sweden to Finland in 1946-70. The third Scandinavian demographic symposium 18-20 June in Tuusula, Finland. Väestöntutkimuksen vuosikirja -
Yearbook of Population Research in Finland XIII. Vammala 1974, pp. 115-124.

Niemi, Einar. Immigration from Northern Finland and Sweden to Northern Norway in the 19th century. Siirtolaisuus - Migration 1976:1, pp. 9-16.

Orta, Timo. Finnish emigration prior to 1893 . Economic, demographic and social backgrounds. The Finnish experience in the Western Great Lake Region: New perspectives ed. by Michael G. Karni et al. Vammala 1975 , pp. $21-35$.

Quick, Holger. Siirtolaisuudesta Suomeen. (On immigration to Finland.) Siirtolaisuus - Migration 1971: 1, pp. 3-8. English summary.

Raivio, Yrjö. Kanadan suomalaisten historia I. (A history of Finns in Canada, I.) Vancouver, British Columbia 1975, 529 pp.

Satakunnan seutukaavaliitto. Satakunnan muuttoliike 1970. Tilastokeskuksen perusaineistoon pohjautuva selvitys Satakunnan kuntien muuttoliikkeestä. (Migration in Satakunta in 1970. A study of migration in the municipalities of Satakunta based on the material of the Central Statistical Office.) Julkaisu A 92. Pori $1974,25 \mathrm{pp}$.

Tapio, Markku. Ulkomaalaiset Suomessa. (Foreigners in Finland.) Siirtolaisuus - Migration 1974:1, pp. 20-22.

Tissari, Jukka. Ruotsiin muuton motiivit. Vojakkalan vastaanottoaseman kautta v. 1970 muuttaneita koskeva tutkimus. (Motives for migration to Sweden. A study of migrants who moved to Sweden through the Vojakkala entrance station.) Työvoimaministeriö. Suunnitteluosasto. Siirtolaisuustutkimuksia 3 . Helsinki $1973,88 \mathrm{pp}$.

Tuomiharju, Tapani. Pakolaisten vastaanottaminen Chilestä ja heidän sijoittamisensa Suomeen. (The reception and placement of Chilean refugees in Finland.) Siirtolaisuus - Migration 1974: 1, pp. $23-26$.

Ulkosuomalaiskongressin $27 \ldots 28.6$. 1975 esitelmät ja puheenvuorot. (The Conference on Finnish emigrants 27.-28. 6. 1975, papers and Jyväskylän kesä 24. 06.-03. 07. 1975. Maija-Liisa Kalhama. 
Siirtolaisuusinstituutti. Siirtolaisuustutkimuksia A 3. Turku 1975, 104 pp.

Walls, Georg. Geografisk rörlighet och selektivitet på arbetsmarknaden (Geographical mobility and selectivity in the labor market.) Meddelanden från statsvetenskapliga fakulteten vid Åbo akademi B: 29, Åbo 1973, 62 pp.

Widen, Bill. Korpobor i America (Emigrants from Korpo in America.) Siirtolaisuusinstituutin tutkimuksia B 1 . Turku 1975, 197 pp.

\section{INTERNAL MIGRATION}

Haavio-Mannila, Elina. Migration and competence: familyorganizational linkages in health and welfare life sector. University of Helsinki. Department of Sociology. Report No 207, 1975, 52 pp.

Hietala, Kari. Työvoiman alueellisen liikkuvuuden taloudelliset vaikutukset. (The Economic consequencies of the regional mobility of manpower.) Sosiaalinen aikakauslehti $1974: 1$, pp. 28-32. English summary.

Inkinen, Irja - Hölttä, Irma. Kuntien välinen muuttoliike 1972: kuntaan muuttaneet iän, sukupuolen ja sivililsäädyn mukaan. (Internal migration between municipalities in 1972: in-migrants in municipalities by age, sex and marital status.) Tilastokeskus. Tilastotiedotus VÅ 1975:4 - Central Statistical Office, Statistical reports VA 1975:4. Helsinki 1975, 31 pp.

Jungner, Yngve. Kaarlelan seudun muuttoliike, vuosisata kehityksen myötä. (Migration of Kaarlela region during one century.) Kokkolan seudun säästöpankki 1874-1974. Kokkola 1974, pp. 65-108.

Juntunen, Esko Kalevi. Maaseudun autioituminen - esimerkkialueena Ruukin kunta. (Desolating of country side - the community of Ruuki, an illustrative example.) Siirtolaisuus - Migration 1976: 2, pp. 13-19.

Jyrkilä, Faina. Fyysinen ja sosiaalinen sopeutuminen. (Physical and social acculturation.) Jyväskylän yliopiston sosiologian laitoksen julkaisu. No 16. Jyväskylä 1976, 148 pp.

Kamppinen, Arto. Muuttoliikkeen kumulatiivinen mekanismi. (The cumulative mechanism of migration.) Lapin tutkimusseuran vuosikirja 14. Tampere 1973, pp. 16-22.

Korpinen, Pirkko. Lahden kaupunkiseudun väestömuutokset vuosina 19611972. (Vital statistics of the region of Lahti, 1961-72.) Lahden kaupungin suunnitteluvirasto, Lahti 1973.

Koski, Riitta. Muuttohalukkuus ja siihen vaikuttavat tekijät Vaasan läänissä. (The desire to migrate and factors affecting it in the province of Vaasa.) Vaasan lääninhallituksen suunnittelutoimisto. Julkaisu 12. Vaasa 1975, 76 pp.

Kosonen, Matti. Kuntien sisäinen muuttoliike Kymen läänissä. (Internal migration between municipalities in the province of Kymi.) Etelä-Karjalan seutukaavaliitto 1974:4. Lappeenranta, 98 pp.

Leppänen, Leena. Pielaveden muuttoliike 1920-1968. (Migration in Pielavesi municipality $1920-1968)$. Helsinki 1973.

Leveelahti, Ilkka. Maassamuuton syistä. Poikkileikkausanalyysi vuodelta 1970. (Causes of migration. A crosscut analysis of 1970). Tampereen yliopiston kansantaloustieteen laitoksen tutkimussarja B:26. Tampere 1973, 41 pp.

Majava, Altti. Lapin muuttoliike haaste yhteiskuntapolitiikalle. (Migration from and to Lappland - a challenge to social policy). Tornionlaakson vuosikirja 1973. Tornio 1973 , pp. 148-160.

Mikkola, Kimmo. Maassamuutto ja pohjoismainen muuttoliike vuonna 1970. (Internal and Nordic migration in Finland in 1970.) Tilastokeskus, Tutkimuksia 22. Central Statistical Office, Studies no 22. Helsinki 1973, 47 pp. English summary.

Naukkarinen, A. - Similä, P., Kunnan sisäinen muuttoliike ja asuntojen käyttö. (Internal migration within a municipality and the use of dwellings). Pohjois-Suomen maantieteilijäin seura r.y. Nordia — Tiedonantoja n:o 3, 1976. 
Niemi, Einar. Siirtolaisuus PohjoisSuomesta ja Pohjois-Ruotsista PohjoisNorjaan 1800-luvulla. (Immigration from northern Finland and northern Sweden to northern Norway in the 19th century). Siirtolaisuus - Migration 1976:1, pp. 9-18.

Nieminen, Seppo. Kemin kaupungin muuttoliike vuonna 1969. (Migration in the city of Kemi in 1969). Pohjalaisten osakuntien aluetutkimustoimikunta, B: 13. Helsinki 1974, 75 pp.

Pihlajarinne, Eero. Muuttoliikkeestä ja sen taloudellisista vaikutuksista lähtöalueelle. (Migration and its economic effects on the place of origin). Lapin tutkimusseuran vuosikirja 14. 1973, pp. 23-29.

Pihlajarinne, Eero. Muuttoliiketutkimus, osa 1. Muuttoliike lähtöalueen taloudellisena ongelmana. (Migration research, part I. Migration as an economic problem of the municipality of departure). Jyväskylä 1973.

Päijät-Hameen seutukaavaliitto. Muuttoliike Päijät-Hämeen maalaiskunnissa v. 1974. (Migration in the rural municipalities of Päijät-Häme). Julkaisu 1976: 1, Hämeenlinna.

Saloheimo, Veijo. Muuttoliikkeet Pohjois-Karjalassa 1600-luvulla. (Migration in North Karelia in the 17th century). Tutkimusprojekti: Pohjois-Karjalan historia. Karjalan tutkimuslaitos. Julkaisu 1974: 8. Joensuu 1974.

Savisalo, U. - Murros, H. Muuttoliikkeen vastaanottaja-alueella kunnalle aiheuttamat investoinnit. (Investments caused by migration to in-migration municipalities). Valtion teknillisen tutkimuslaitoksen rakennus- ja yhdyskuntatalouden laboratorion tiedonanto N:o 6, Helsinki, 1974.

Selvitys muuttoliikkeen ja alueellisen väestönmuutoksen hyötyjä ja kustannuksia käsittelevistä tutkimuksista. Mprojekti. (A report on research concerning the gain and cost of migration and regional population movement). Helsingin yliopiston sosiologian laitos. Monisteita 8. Helsinki 1975, $104 \mathrm{pp}$.

Wiman, Ronald. Työvoiman kansainvälisen muuttoliikkeen mekanismi. Tut- kimus Ruotsiin muuton syistä. (The mechanism of international labour migration. A study of the causes of Finnish emigration to Sweden). Elinkeinoelämän tutkimuslaitos. Julkaisuja, Sarja B:9, $216 \mathrm{pp}$. English summary.

Ylärakkola, Arvo. 80 vuotta ruotsinsuomalaista siirtolaistoimintaa. (Eighty years of activity among Finnish-Swedish immigrants.) Tukholman Suomalainen Seura 80 vuotta. Tukholma 1974, 150 pp.

\section{J. CHARACTERISTICS}

Allardt, Erik. Finlandssvenskarna. (The Swedish-speaking population in Finland). Historiska och literaturhistoriska studier 1974, pp. 302-320.

Haavio-Mannila, Elina - Johansson, Sten. Finska utvandrares levnadsnivå i Sverige. (The standard of living of Finnish immigrants in Sweden). Sosiologia 1974: 4, pp. 192-204.

Haavio-Mannila, Elina - Stenius, Kerstin. Immigration and mental health. Department of Sociology. University of Helsinki. Publication 195. Helsingin yliopiston sosiologian laitos. Tutkimuksia. 1973, $36 \mathrm{pp}$.

Heikkilä, Lena. Lapsen syntymästä perheelle aiheutuvat kulut. (The cost of childbirth to the family). Sosiaalinen aikakauskirja $1973: 4$, pp. 433-439.

Heikkilä, Lena. Synnyttäjien raskauden aikaiseen ansiotyössä käyntiin liittyvistä tekijöistä sekä lapsen syntymän perheelle aiheuttamista kustannuksista. (Factors related to the employment of the mother during pregnancy and the cost of childbirth to the family.) Sosiaalija terveysministeriö. Sosiaalipoliittinen tutkimusosasto. Tutkimuksia 1973: 10, 86 pp.

Hietala, Kari. Siirtolaisuuden taloudelliset syyt ja seuraukset. (Economic reasons for and consequences of emigration). Siirtolaisuustutkimusten lähtökohtia. Työvoimaministeriön siirtolaisuustutkimuksia 1, Helsinki 1973, pp. 41-90.

Hoikkanen, Silja. Suomen kaupunkien väestön ikärakenne vuosina 1960 ja 1970 . 
(The age structure in Finnish cities in 1960 and 1970). Terra $1975: 4$, pp. 245251.

Koivukangas, Olavi-Laakso, Leo. Suomalaisten siirtolaisten sosiaali-lääketieteellisistä ongelmista Austraaliassa. (The socio-medical problems of Finnish immigrants in Australia). Siirtolaisuus - Migration. 1975: 1, pp. 9-21.

Korpelainen, Lauri. Maastamuutto köyhdyttävää vientiä. (Emigration - an impoverishing export). Unitas 1973:2, pp. $71-83$.

Kuokkanen, Aarne. Tampereen väestö ikäryhmittäin 01.101.1973 osa-aluejaon mukaan. (The population of Tampere by agegroups according to the division into areas of 01.01 .1973 ) Tilastollisia tiedonantoja Tampereelta $1973: 4$, pp. 118-125.

Lahtinen, Yrjö. Pääkaupunkiseudun työvoimatutkimus. Tutkimus pääkaupunkiseudulla asuvien työllisyydestä, työolosuhteista ja työmatkoista. (A study of the labor force participation, working conditions and trips to and from work of inhabitants living in Helsinki and its environs.) Helsingin seudun yhteiskuntatutkimuksen neuvottelukunta. Pääkaupunkiseudun julkaisusarja B 1. Helsinki 1975.

Myrskylä, Pekka. Perheiden rakenne ja perheen huoltajien ammatissatoimivuus väestölaskennan mukaan. (Family composition and the family wage-earner's working capacity. According to the population census). Sosiaalinen aikakauskirja 1974: 2, pp. 381-386, English summary.

Riihinen, Olavi. Kaupungistuminen ja ulkoiset säästötekijät. (Urbanization and external economical factors). In Sosiaalipolitiikan arvot, tavoitteet ja käytäntö 1970-luvulla, pp. 149-160. Tampere 1973.

Ruokonen, Merja. Väestörakenne ja asuntokanta pääkaupunkiseudulla. (The population structure and housing in the region of Helsinki). Helsingin seudun yhteiskuntatutkimuksen neuvottelukunta. Helsinki 1975, 68 pp. Pääkaupunkiseudun julkaisusarja A: 1 .

Toivonen, Timo. Suomen ammatissa toimivan maatalousväestön luokkarakenteen kehitys vuosina 1901-1920. (The development of the class structure of the economically active rural population in 1901-1920.

Toivonen, Timo. Suomen teollisuuden ammatissa toimivan väestön luokista ja kerrostumista vuosina $1950-1970$. (The classes and stratums of the economically active population working in industry in $1950-1970$ ). Sosiologia $1975: 1$, pp. $2-$ 11.

\section{K. DEMOGRAPHIC AND ECONOMIC INTERRELATIONS}

Bank of Finland, Monthly Bulletin. The common labour market of the Nordic countries and emigration. 1975: 5 , pp. $1-2$.

Fougstedt, Gunnar. Effects of demographic factors on the demand for education in view of manpower requirements. In Education and population, Mutual Impacts. Ed. H. V. Muhsam. Ordina Editions, Dolhain 1975.

Hietala, Kari. Muuttohalukkuus ja informaatio. (The propensity to migrate and information). Siirtolaisuus-informaatiokampanjan seurantatutkimuksen 1. osavaihe. Työvoimaministeriö. Suunnitteluosasto. Siirtolaisuustutkimuksia 7. Helsinki 1974, 165 pp.

Koivula, Samuli. Maaseudun väestökato ja kuntien toiminnan ja talouden muutokset. (Rural depopulation and changes in the economy and functioning of municipalities). Sosiaali- ja terveysministeriö. Sosiaalipoliittinen tutkimusosasto. Tutkimuksia 1973:3, $70 \mathrm{pp}$.

Korpelainen, Lauri. Väestö- ja työvoimakehitys. (Population and labor force development). Työvoimakatsaus 1975:2, pp. $1-8$.

Lankinen, Markku. Tutkimus väestön ammatissatoimivuudesta ja siihen vaikuttavista tekijöistä Helsingissä sekä ennuste vuodelle 1985. (A study of gainful employment and factors which affect it in Helsinki and a forecast for 1985). Helsingin kaupungin kaupunkisuunnitteluvirasto. Yleiskaavaosasto 2. Helsinki 1973, 60 pp.

Laukkanen, Pertti. Kemin-Tornion työ- 
voimatutkimus. (A study of the labor force in Kemi-Tornio). Työvoimaministeriö. Suunnitteluosasto. Tutkimuksia 12, 1975, 224 pp.

Lindgren, Jarl - Railimo, Sirpa. Opintonsa päättäneiden nuorten hakeutuminen työelämään. (The entrance into working life of young people who have completed their studies.) Työvoimaministeriö. Suunnitteluosasto. Tutkimuksia 14. Helsinki 1975, 94 pp.

Manninen, Paavo. Muuttoliiketutkimus 2. Muuttoliike ja maalaiskuntien finanssitalous. Tutkimus maassamuuton ja kunnallisen finanssitalouden välisistä suhteista 1960-luvun lopulla Suomessa. (Migration and the fiscal economy of rural communities at the end of the $1960 \mathrm{~s}$ in Finland). Jyväskylän yliopisto, Taloustieteen laitos, julkaisu 14, 1974, 64 pp.

Myrskylä, Pekka. Väestö ja työvoiman tarjonta. (Population and the supply of labor force). Suomen tilastoseuran vuosikirja 1975, pp. 133-140.

Pohjois-Karjalan kehitysnäkymät. Väestö ja elinkeinoelämä. (North Karelia prospects: Population and industries). Joensuu 1973, 172 pp.

Purola, Tapani. Työikäisten lisäys ei välttämättä kasvata työvoimaa. (An increase in the working-age population does not necessarily mean a larger labor force.) Sosiaalinen aikakauskirja 1976:1, pp. $27-31$.

Seppänen, Jaakko. Työvoiman tarjonta ja työpaikkatavoitteet Keski-Suomen läänissä vuoteen 1980 mennessä. (The supply of labor force and employment goals in the province of Central Finland up to 1980). Työvoimaministeriön suunnitteluosasto. Tutkimuksia 7. Helsinki 1974, 113 pp.

Tainio, Risto. Työvoiman liikkuvuus ja siihen vaikuttaneet tekijät Suomessa ennen toista maailmansotaa. (The mobility of the labor force and factors affecting it before the Second World War). Helsingin teknillinen korkeakoulu, Helsinki 1975, $101 \mathrm{pp}$.

Träsk, Inger. Naiset työmarkkinoilla Suomessa ja Ruotsissa - vertailu. (Women on the labor market in Finland and Sweden - a comparison). Sosiaali- nen aikakauskirja $1973: 5$, pp. 511-528.

Wiman, Ronald. Työvoiman Ruotsiin muuton syyt. (Why there is a migration of the labor force to Sweden). Sosiologia 1975: 23 , pp. $55-63$.

\section{OTHER INTERRELATIONS}

Lallukka, Seppo. Syntyvyys ja sosialismi. Tutkimus syntyvyyden ja eräiden sosioekonomisten sekä kulttuuristen tekijöiden yhteyksistä Neuvostoliitossa. (Fertility and socialism. A study on the relationship between fertility and some socio-economic and cultural factors in the Soviet Union). Helsingin yliopiston sosiaalipolitiikan laitos. Tutkimuksia 6, 1976, 271 pp.

Leppo, Kimmo. Väestönkasvu, terveydenhuolto ja kehitysyhteistyö. (Population growth, public health care and international cooperation on development). Suomen lääkärilehti 1973: 28, pp. 12231232.

Leveelahti, Ilkka. Maassamuutto eri komponenttien riippuvuudesta kunnan ominaisuuksista - poikkileikkausanalyysi vuodelta 1970. (Internal migration depending on different characteristics of the municipality. A periodical analysis in 1970). Tampere 1975.

Lindgren, Jarl. Law and fertility in Finland. In law and fertility in Europe. A study of legislation directly or indirectly affecting fertility in Europe. Ed. Maurice Kirk, Massimo Livi Bacci and Egon Szabady. UISSP 1975.

Mehtonen, Pentti - Koskiaho, Briitta. Tiedotus kansainvälisissä väestökysymyksissä. (The diffusion of international population matters). Tampereen yliopiston sosiaalipolitiikan laitoksen tutkimuksia no 39. Tampere $1975,105 \mathrm{pp}$.

Nevanlinna, Harri Rolf. Suomen väestörakenne. Geneettinen ja genealoginen tutkimus. (Population structure in Finland. A genetic and genealogical study). Kansaneläkelaitoksen julkaisuja A: 9 , Helsinki 1973, 128 pp.

Wiman, Ronald. Työvoiman Ruotsiin muuton syyt. (Causes of Finnish migration to Sweden). Sosiologia 1975:2, pp. 55-63. 


\section{POLICIES}

Aarnio, Aulis. Väestöpolitiikka, perhepolitiikka ja avioliittolaki. (Population policy, family policy and marriage law). Suomalainen lakimiesyhdistys. Julkaisu 611 Helsinki 1973, pp. 372-378.

Auvinen, Riitta. De l'avenir de la famille et de la politique familiale. (The future of the family and family policy). Väestöntutkimuslaitoksen julkaisuja, sarja B: 37 - Publications of Population Research Institute, series B: 37 . Helsinki $1974,17 \mathrm{pp}$.

Filpus, Timo. Siirtolaisuus ja Suomen työvoimapolitiikka. (Emigration and Finnish labor force policy). Kyyhkynen 1973: 4. Heinola, pp. 10-12.

Kiiskinen, Auvo. Aluepolitiikkamme nykyvaiheen tarkastelua. (Finnish regional development policies in perspective). Kansantaloudellinen aikakauskirja 1974: 1, pp. 3-25.

Lallukka, Seppo. Huomioita Unkarin väestöpolitiikasta. (On the population policy of Hungary.) Sosiaalinen aikakauskirja, 1975: 2, pp. 154-170.

Leppo, Kimmo. Reunahuomautuksia väestöpolitiikasta käytyyn keskusteluun. (Marginal notes on the discussion on population policy). Sosiologia 1973: 3 , pp. 110-119.

Lindgren, Jarl. Aspects of the population questions in Finnish social development policy. Väestöntutkimuksen vuosikirja - Yearbook of Population Research in Finland XIV, Vammala 1976, pp. $17-29$.

Lindgren, Jarl. 1970-luvun väestöpolitiikan sisällöstä. (On the content of population policy in the 1970s). In Sosiaalipolitiikan arvot, tavoitteet ja käytäntö 1970-luvulla. Tampere 1973, pp. 177-185.

Lindgren, Jarl. Väestöpoliittisista tavoitteista, keinoista ja saavutuksista teollistuneissa maissa. (Population policy goals, methods and achievements in industrialized countries). Sosiaalinen Aikakauskirja 1974: 5, pp. 402-407, English summary.

Piepponen, Paavo. Population policy in Finland. Population policy in developed countries. Edited by Bernard Berelson.
New York 1974. A Population Council Book, pp. 98-112.

Sipponen, Kauko. Väestöpolitiikka yhteiskunnallisessa päätöksenteossa. (Population policy in society's decision making). In Laskeva syntyvyys - lamautuva yhteiskunta. Väestöliitto. Kolmikantasarja 5, pp. 3-19. Helsinki 1975.

Sipponen, Kauko-Hulkko, Jouko. The population situation in Finland and the population policy it require. Väestöntutkimuksen vuosikirja - Yearbook of Population Research in Finland XIV, Vammala 1976, pp. 9-16.

Soininen, Veli. Väestöennusteet ja aluepolitiikka. (Population forecasts and regional policy). Suunnittelumaantiede 1974, pp. $65-72$.

Suominen, Leena. Family policy motives behind proposals in the Finnish Parliament. Väestöntutkimuksen vuosikirja - Yearbook of Population Research in Finland XIV. Vammala 1976, pp. 3041.

Suominen, Leena. Perhepolitiikan perustelut Suomessa. (Family policy motives behind proposals in the Finnish Parliament). Väestöntutkimuslaitoksen julkaisuja, sarja B: 36 - Population Research Institute, series B: 36 . Helsinki, $141 \mathrm{pp}$.

Suominen, Risto. Lapsiperheille annetun tuen kasaantuminen. (Increasing the aid given to families with children). Sosiaali- ja terveysministeriö. Tutkimusosasto. Julkaisuja 3, 1974, 67 pp. Also in Sosiaalinen aikakauskirja 1974: 5, pp. 415-422. English summary.

Suominen, Risto. Sosiaalisten tulonsiirtojen kohtaanto. Osa: Perhepoliittisten tulonsiirtojen kohtaanto. (The incidence of social transfers. Part: The incidence of family policy transfers). Sosiaali- ja terveysministeriö. Tutkimusosasto. Julkaisuja 8, 1976, $78 \mathrm{pp}$.

Suominen, Risto - Rinne, Risto. Perhekustannusten tasaus Suomessa vv. 19361971. (Levelling family expenses in Finland). Sosiaali- ja terveysministeriö. Sosiaalipoliittinen tutkimusosasto: Julkaisuja 9, 1973. Helsinki 1973, 61 pp.

Stolte-Heiskanen, Veronica. "Holistic» vs. "particularistic" approaches to family 
policy. Helsingin yliopiston sosiologian laitos. Tutkimus 187. Helsinki 1973, $13 \mathrm{pp}$.

Stolte-Heiskanen, Veronica. Väestöpoliittisista malleista. Perhesuunnittelu tai sosiaalistaloudellinen kehitys. (On population policy models. Family planning or socio-economic development). Medisiinari 1974: 5, pp. 44, 47, 49-51, 54.

Työvoimaministeriön siirtolaisuustutkimusten ohjelma 1973. (Ministry of Labor. The emigration research program for 1973). Työvoimaministeriö. Suunnitteluosasto. Siirtolaisuustutkimuksia 2. Helsinki 1973, 92 pp.

\section{N. METHODS OF RESEARCH AND ANALYSIS}

Herva, Aslak. Alueellisten jakaumien sentrometria (The centrometre of spatial distribution), Helsingin yliopiston sosiaalipolitiikan laitos, Tutkimus 1976: 3, 55 pp.

Herva, Aslak. Demografisista makrotason simulointimalleista (Demographic simulation models on the macro level) Suomen Väestötieteen yhdistyksen julkaisuja n:o 1, 1975, 33-44 pp.

Herva, Aslak. Demografisista malleista. (On demographic models). Sosiologia, 1976:2 pp. 66-74.

Herva, Aslak. The regional optimal population points in Finland. Väestöntutkimuksen vuosikirja - Yearbook of Population Research in Finland, XIV, Vammala 1976, pp. 95-102.

Karivalo, Merja. An absorption analogy for the study of population migration. Fennia 1976: 148, pp. 19-32.

Koskela, Lauri-Nevalainen, Risto. Alueellinen väestö- ja työvoimamalli. (A regional population and labor force model). Taloudellinen suunnittelukeskus 1976.

Kulokari, Hannu. Experiments on normative population projection. Optimizing the longterm activity rate. Väestöntutkimuksen vuosikirja - Yearbook of Population Research XIV, 1975-76, Vammala pp. $85-94$.
Laaksonen, Seppo. Määrälliset väestön koulutus- ja työvoimamallit. (Quantitative population education and labor force models.) Helsingin yliopiston sosiaalipolitiikan laitos. Tutkimus 7, 1976, $92 \mathrm{pp}$.

Leppo, Kimmo - Koskelainen, OsmoSievers, Kai. Seksuaalikäyttäytymistä ja ehkäisytapoja koskevan tutkimuksen metodiraportti. (Report on methods used in the study on sexual behavior and contraceptive practises.) Väestöntutkimuslaitoksen julkaisuja, sarja B: 33 - Publications of Population Research Institute, Series B: 33, Helsinki 1973, 159 pp.

Naukkarinen, Arvo. The application of areal demographic development types to population projections. A case study on Northern Ostrobothnia, Finland. Fennia n:o 125 . Helsinki 1973, $31 \mathrm{pp}$.

Nieminen, Mauri. Demografinen väestöennuste. (Demographic population forecast). Yhdyskuntasuunnittelun jatkokoulutuskeskus. Vuosikirja 1972-1973. Otaniemi 1974, pp. 170-180.

Rikkinen, Kalevi. Kohorttianalyysi väestömaantieteellisessä tutkimuksessa. (Cohort analysis in population demography research). Terra $1974: 3$, pp. 124129.

Salo, Mikko A. Syntyvyyden ekonomisesta ja sosioekonomisesta mikroanalyysistä (On the economic and socio-economic micro analysis of fertility). Turun yliopiston sosiaalipolitiikan laitos. Tutkielma 13:26. Turku 1975, 14 pp.

Turpeinen, $\mathrm{O}$. Norden och den befolkningshistoriska forskningen. (Scandinavia and historical population research). Historisk Tidskrift för Finland 1976: 1.

\section{O. ORGANIZATION AND ADMINIS- TRATION}

Etelä-Karjalan seutukaavaliitto. Taloudellis-demografinen väestö- ja työpaikkaennustejärjestelmä. (An economicdemographic population and employment system). Julkaisu 2, 1975, Lappeenranta, $24 \mathrm{pp}$. 
Helsingin kuntasuunnitteluryhmä. Väestösuunnitteen tarkistusperusteet. (Principles for controlling population planning figures). Helsinki, 1975.

Komiteanmietintö 1975: 11. Maailman väestövuoden komitean mietintö. (The report of the committee on the World Population Year). Helsinki 1975, 148 pp.

Kåhre, Inga. Väestörakenteen heterogeenisuus aluesuunnittelun tavoitteena. (The heterogeneity of the population structure as the goal of regional planning). Helsingin teknillisen korkeakoulun arkkitehtiosaston julkaisu. Otaniemi 1974, 85 pp.

Romppanen, Antti. Väestö- ja työvoimaennusteiden laadinnasta. (Making population and labor force forecasts). Suomen tilastoseuran vuosikirja 1975, pp. 123-132.

Savela, Veikko. Väestösuunnitteet ja niiden asema ennusteiden tuotannossa. (Population figures and their role in forecast production). Suomen tilastoseuran vuosikirja 1975 , pp. $150-159$.

Siirtolaisasiain neuvottelukunnan mietintö II. Selvityksiä ja ehdotuksia (The II report of the migration commission. Statements and proposals). Komiteanmietintö 1974:64, Helsinki 1974, 64 pp.

Siirtolaisasiain neuvottelukunnan mietintö IV. Toimenpide-ehdotuksia. (The IV report of the migration commission. Proposals and measures). Komiteanmietintö 1976: 81. Helsinki 1976, 99 pp.

Valtioneuvoston kanslia. Väliraportti lääneittäisen työpaikka- ja väestösuunnitteen laatimisesta vuodelle 1980 . (Planning figures for employment and population until 1980 by provinces. An interim report.) Julkaisu 10, 1974. Helsinki 209 pp.

Valtioneuvoston kanslian väestöennusteryhmä. Väestöennusteiden laadinnan järjestäminen. (Organizing population forecasting). Julkaisu 1, 1973, pp. 88.

Väestö- ja työpaikkaennusteet yleiskaavallisessa suunnittelussa. Esitutkimus. (The use of population and job forecasts in making master plans. A pilot study.). Sisäasiainministeriön kaavoitus- ja rakennusosasto, tutkimusraportti 50, 1975.

\section{P. PROFESSIONAL MEETINGS AND CONFERENCES}

Demografiset tiedostot ja tutkimustarpeet. Tvärminnessä 09-10. 10. 1975 järjestetyn jatkokoulutusseminaarin alustukset. (Demographic information and the need for research). Suomen väestötieteen yhdistyksen julkaisuja. Published by the Finnish Demographic Society. Helsinki $1976,60 \mathrm{pp}$.

Laskeva syntyvyys - lamautuva yhteiskunta. (Decreasing fertility - a paralyzed society). Ed. by Kalle Justander. Väestöliitto. Kolmikantasarja 5. Helsinki 1975, $117 \mathrm{pp}$.

This includes among others:

Sipponen, Kauko. Väestöpolitiikka yhteiskunnallisessa päätöksenteossa. (Population policy and decision making in society), pp. 3-19.

Hulkko, Jouko. Suomen väestönkehitys verrattuna muiden Euroopan valtioiden väestönkehitykseen. (Population development in Finland compared with that of other European countries), pp. 20-41.

Visuri, Elina. Suomalaisten perhekoko - sattuma vai suunnitelma. (Finnish family size - accidental or planned), pp. $42-53$.

Kenttä, Aaro. Suomen väestönkehityksen vaihtoehtoja. (Alternative population trends in Finland), pp. 54-69.

Korpelainen, Lauri. Väestönkehityksen eri vaihtoehtojen vaikutukset työvoiman tarjontaan ja kysyntään. (The effect of alternative population development on the supply and demand of labor), pp. $70-74$.

Piepponen, Risto. Väestönkehityksen vaihtoehtojen vaikutus kauppaan ja teollisuuteen. (The effect of alternative population development on industry and commerce), pp. 75-80.

Purola, Tapani. Maamme väestönkehitys ja sosiaali- ja terveyspolitiikan tarpeet. (Population development and social and health policy needs in Finland), pp. 81-88.

Strömmer, Aarno. Väestönkehitys ja asuntopolitiikka. (Population development and housing policy), pp. 94-97. 
Justander, Kalle. Väestönkehityksen vaikutus perhepolitiikkaan. (The effect of population development of family policy), pp. 98-105.

Lindgren, Jarl. Vuoden 1974 syntyvyyden kasvu. (The increase of fertility in Finland in 1974) pp. 106-117.

Migration research in Scandinavia. The proceedings of the Nordic seminar on migration research held at Siikaranta, Finland on January 3-5, 1973. Ministry of Labour. Migration reports 4, ed. by Altti Majava Helsinki 1973, 337 pp.

This includes among others:

Allefresde, Maurice. Finnish emigration to Sweden and its consequences in the context of European migration, pp. 4-11.

Majava, Altti-Tapio Markku. Emigration research in Finland, pp. 20-27.

Pentinmäki, Erkki, Migration and other statistics - Problems and potentials for use, pp. $38-42$.

Mikkola, Kimmo. Migration in Finland in 1970 , pp. $62-70$.

Haavio-Mannila, Elina. The consequences of migration for individuals and families, pp. 103-116.

Jaakkola, Magdalena. The social networks of Finnish migrants, pp. 117-124.

Hietala, Kari. The economic causes and consequences of emigration, pp. 115-196.

Edgren, Christian-Wiman, Ronald. The structure of time-lags between the decision and the start of migration, $\mathrm{pp}$. 208-281.

Lind, Jouko - Salmela-Mattila, Juhani. The Situation of the worker in Finland and Sweden, pp. 232-236.

Korva, Timo. Real incomes of industrial workers in Finland and Sweden in 1971, pp. $237-241$.

Heikkinen, Sirkka-Liisa. A study on return migration, pp. 242-247.

Koivukangas, Olavi. Finnish migration to Australia with special reference to the postwar period, pp. 248-255.

Majava, Altti. Emigration from Finland, pp. $275-305$.

Muuttoliikesymposium $\quad 20-21.11 .1975$ (Symposium on emigration) ed. by Olavi
Koivukangas, Raimo Narjus and Sakari Sivula. Siirtolaisuusinstituutti. Siirtolaisuustutkimuksia A 4. Turku 1976.

Jutikkala, Eino. Maassamuuton historiaa (A history of migration), pp. 15-19.

Allefresde, Maurice. Maassamuutto Euroopassa. (Migration in Europe), pp. 2028.

Kenttä, Aaro. Maassamuutto kotimaassa. (Migration in Finland), pp. 29-33.

Tauriainen, Juhani. Muuttoliikkeen yhteiskunnalliset seuraukset. (The social consequences of migration), pp. 35-45.

1. Muuttajan muotokuva - muuttajan motiivit ja valinnat (A portrait of the migrant - his motives and choices). Ilkka Leveelahti, Pekka Huuhtanen, Lauri Hautamäki, pp. $49-67$.

2. Yksilö ja aluepolitiikka (Individual and regional policy).

Maassamuuton ohjaus (The guidance of migration). Jouko Kajanoja, Arto Salmela, Timo Relander, Juha Talvitie, Veikko Tattari, Eero Koivukoski, K. J. Brunström, pp. 71-104.

Sijoittumisen vapaus ja ohjaus (The freedom to settle and the guidance of settlement). Hannu Kauppi, Pekka Rekola, Turo Bergman, Tauno Ranta, pp. 104-123.

Yksilön sopeutuminen muuttuvaan ympäristöön, (The adjustment of the individual in a changing environment). Jouni Apajalahti, Matti Aaltonen, AkuKimmo Ripatti, Elina Haavio-Mannila, pp. $124-146$.

Maassamuuton ohjaus - massamuuton ohjaustako? (The guidance of internal migration - is it guidance of massmigration?) Roger Broo, Vilho A. Koiranen, Paavo Lipponen, Hemmi Pääkkönen, Juhani Tuomaala, pp. 156-169.

Proceedings of the Nordic seminar on the long-term effects of migration May $27-29,1974$. Ed. by I. Widgren, Stockholm 1976.

These include among others:

Majava, Altti. Migration problems in the long-term perspective, pp. 9-17.

von Bonsdorff, Göran. The political effects of migration, pp. $40-51$.

Haavio-Mannila, Elina. Effects of the length of stay in Sweden on the social 
situation of married Finnish immigrants in Västerăs, pp. 67-81.

Heikkinen, Sirkka-Liisa. Return migration from Sweden to Finland, pp. 108124.

Hietala, Kari. Migration in view of optimal population theory, pp. 125-164.

Jaakkola, Magdalena. Finnish immigrants in Swedish politics, pp. 169-181.

Lehtonen, Kaarina-Hägen, Kerstin. The effects of the duration of stay in Sweden on the level of living of Finnish immigrant workers, pp. 190-202.

Lind, Jouko. The position and working of Finnish workers in Sweden, pp. 203209.

Myrskylä, Pekka. The characteristics of Finnish migrants and the propensity to move, pp. $210-224$.

Savela, Veikko. The costs of rearing and educating a child in Finland over the long run, pp. 237-253.

Tapio, Markku. The prospects for structural change and migration in Finland during the next decade, pp. 254295.

Majava, Altti. The 1974 Sopemi report for Finland, pp. $354-371$.

Seminarium kring Finlands befolkningsfråga i Helsingfors 12.10.1974. The seminar on the population question in Finland, held by Svenska befolkningsförbundet i Finland. Helsinki on December 10, 1974.

This include among others:

Fougstedt, Gunnar. Befolkningsläget i Finland. (The population situation in Finland).

Meinander, Nils. Ekonomisk synpunkter på Finlands befolkning (Economic aspects of the population of Finland).

Allardt, Erik. Sociala konsekvenser av befolkningsutvecklingen i Finland. (Social consequences of the population trends in Finland).

Forsberg, Karl-Erik. Finlandssvenskarna. (The Swedish-speaking population of Finland).

The third Scandinavian demographic symposium 18-20 June 1973 in Tuusula,
Finland. The Scandinavian demographic society. Scandinavian population studies 3. Helsinki 1974, $150 \mathrm{pp}$.

This includes among others:

Leppo, Kimmo - Koskelainen, Osmo Sievers, Kai. Contraceptive practices in Finland in 1971, pp. 47-60.

Sippola, Matti. Depopulation in developing areas and the effect this has upon the social environment and development policy, pp. 95-100.

Mikkola, Kimmo. Return migration from Sweden to Finland in 1946-1970, pp. 115-124.

Matthiessen, P. C. Population stabilization in the Nordic countries, pp. 83-94.

\section{Q. BIBLIOGRAPHIES}

A bibliography of Finnish Population Research 1969-1972. Väestöntutkimuksen vuosikirja - Yearbook of Population Research in Finland XIII, 1973-74. Vammala 1977, pp. 176-190.

Laaksonen, Pirjo. Kansantaloustieteellinen kirjallisuus Suomessa 1960-1972 I. (A bibliography of literature on economics in Finland 1960-1972 I). Helsingin kauppakorkeakoulun kirjasto, julkaisu 24. Helsinki 1975 , pp. $15-20$.

Maailman väestövuoden 1974 tietopaketti. - The Finnish Population and Family Welfare Federation Väestöliitto. 1974, 36 pp.

Orrman, Eljas. Suomen asutuksen yleisluettelon opas. (A guide to the general list of Finnish settlement). Valtionarkisto, julkaisu 7. Helsinki 1975, $54 \mathrm{pp}$.

Pirilä, Marja. Kansantaloustieteellinen kirjallisuus Suomessa 1974. (A bibliography of literature on economics in Finland in 1974). Helsingin kauppakorkeakoulun julkaisuja D-8, Helsinki 1976, pp. $14-19$.

Pirilä, Marja. Kansantaloustieteellinen kirjallisuus Suomessa 1975 (A bibliography on litterature on economics in Finland). Helsingin kauppakorkeakoulun julkaisuja D-18, Helsinki 1977, pp, 15-20

Pääkaupunkiseutua koskevat 01.01. 1974 jälkeen ilmestyneet sekä tekeillä 
ja suunnitteilla olevat tutkimukset. (Studies concerning the Helsinki area, published after the 1st of January, 1974 as well as those underway or in the planning stage). Pääkaupunkiseudun julkaisusarja 1974: II: 2.

Tutkimusluettelo Helsingin seutua koskevista yhteiskuntatutkimuksista 01.09. 1973. (A list of social policy studies concerning the Helsinki area as of September 1st, 1973). Pääkaupunkiseudun julkaisusarja 1973: I 4. Helsinki 1973, pp. 13-17.

Tutkimusluettelo Helsingin seutua koskevista yhteiskuntatutkimuksista 01.09. 1975. (A list of social policy studies concerning the Helsinki area). Helsingin seudun yhteiskuntatutkimuksen neuvottelukunta. Pääkaupunkiseudun julkaisusarja I 10. Helsinki 1975.

Tutkimusluettelo pääkaupunkiseutua koskevista yhteiskuntatutkimuksista 01 . 11.1976. (A list of social policy studies concerning the Helsinki area as of November 1st, 1976). Pääkaupunkiseudun yhteistyövaltuuskunta: Julkaisu 1976:17. Helsinki 107 pp.

Vaisto, Erkki. Kansantaloustieteellinen kirjallisuus Suomessa 1973. (A bibliography of literature on economics in Finland 1973). Helsingin kauppakorkeakoulun kirjaston julkaisuja 21. Helsinki 1974, pp. 13-17.

\section{S. OFFICIAL STATISTICAL PUBLICATIONS}

Helsingin kaupungin henkikirjoitettu väestö 1972. (The population of Helsinki according to the registration lists of 1972). Tilastollisia kuukausitietoja Helsingistä - Statistical Monthly Review of Helsinki $1973: 3$, p. 98.

Helsingin kaupungin henkikirjoitettu väestö 1973 (The population of Helsinki according to the registration lists of 1973). Tilastollisia kuukausitietoja Helsingistä - Statistical Monthly Review of Helsinki 1974: 3, p. 131.

Helsingin kaupungin henkikirjoitettu väestö 1974. (The population of Helsinki according to the registration lists of 1974). Tilastollisia kuukausitietoja Helsingistä - Statistical Monthly Review of Helsinki $1974: 12$, p. 541.

Helsingin kaupungin henkikirjoitettu väestö 1975. (The population of Helsinki according to the registration lists of 1975). Tilastollisia kuukausitietoja Helsingistä - Statistical Monthly Review of Helsinki 1975 : 12 , p. 459.

Helsingin kaupungin tilastollinen vuosikirja 1972. (Statistical abstract of the City of Helsinki 1972). Helsinki 1973, $347 \mathrm{pp}$.

- 1973, 1974, $339 \mathrm{pp}$.

- 1974, 1975, $353 \mathrm{pp}$.

- 1975, 1976, 359 pp.

Kansaneläkelaitoksen tilastollinen vuosikirja 1971. (Statistical Yearbook of the National Pensions Institute of Finland 1971.) Helsinki 1973, 393 pp.

- 1972, 1974, $160 \mathrm{pp}$.

- 1973, 1974, $160 \mathrm{pp}$.

- 1974, 1975, $163 \mathrm{pp}$.

- 1975, 1976, 166 pp.

Kunnittainen väestöennuste 19752010. (Population projection by communes 1975-2010). Tilastokeskus, Tilastotiedotus VA 1975:12 - Central Statistical Office, Statistical Reports VA 1975: $12,71 \mathrm{pp}$.

Kuolemansyyt 1965. (Causes of death in Finland 1965). SVT VI: 121 - Official Statistics of Finland VI B:121. Helsinki 1974, $101 \mathrm{pp}$.

$-1966,1974$, SVT VI B: 123,101 pp.

$-1967,1974$, SVT VI B: 124, $101 \mathrm{pp}$.

$-1968,1976$, SVT VI B: 125, $101 \mathrm{pp}$.

- 1969, 1973, SVT VI B: 126,93 pp.

$-1970,1973$, SVT VI B: 122,139 pp.

$-1971,1974$, SVT VI B: 127,108 pp.

$-1972,1975$, SVT VI B: $128,101 \mathrm{pp}$.

$-1973,1976$, SVT VI B: 129,116 pp.

Kuolleisuus- ja eloonjäämislukuja 1971. (Life tables 1971). Tilastokeskus, Tilastotiedotus VA 1974:13 - Central Statistical Office, Statistical Reports VA 1974: 13, 4 pp.

— 1972 VÄ 1975: 9, 4 pp.

- 1973 VÄ 1975: 25, 7 pp.

- 1974 VÄ 1976: 11, 6 pp.

Kuolleisuus. Kuolleisuus- ja eloonjäämistaulukoita 1966-1970. (Life tables 
1966-70). SVT VI A: 134 - Official Statistics of Finland VI A: 134, 1974, $30 \mathrm{pp}$.

Mäenpää, Jalo. Väestörekisterin pito ja sen nykyongelmat. (The population register and its current problems). Seurakuntien talousneuvoston julkaisuja 15. Helsinki 1975 , pp. $61-68$.

Suomen tilastollinen vuosikirja 1972. (Statistical Yearbook of Finland 1972.) Helsinki 1973, 549 pp.

- 1973, 1974, 547 pp.

- 1974, 1975, $539 \mathrm{pp}$.

- 1975, 1976, $535 \mathrm{pp}$.

Tampereen kaupungin tilastollinen vuosikirja 1972. (Statistical Yearbook of the City of Tampere 1972). Tampere 1973, $174 \mathrm{pp}$.

- 1973, 1974, $176 \mathrm{pp}$.

- 1974, 1975, $176 \mathrm{pp}$.

- 1975, 1976, 180 pp.

Tilastokatsauksia. (Bulletin of Statistics.) Tilastokeskus - Published by the Central Statistical Office of Finland. Helsinki 1973-1976.

Tilastollisia kuukausitietoja Helsingistä 1973-1976. (Statistical Monthly Review 1973-1976.) Published by the Statistical Office of the City Helsinki. Helsinki.
Tilastollisia tiedonantoja Tampereelta 1973-1976. (Statistical Bulletin of the City of Tampere 1973-1976.) Published by the Statistical Office of Tampere.

Turun kaupungin tilastollinen vuosikirja 1972/73. (Statistical Yearbook of the City of Turku 1972/73.) Published by Turku Office of Statistics. Turku 1974, $265 \mathrm{pp}$.

-1974/75, 1976, 267 pp.

Väestönlaskenta 1970. (Population census 1970). SVT VI C 104 , osat I-XIX (Official Statistics of Finland, VI C 104, Volumes I-XIX. 1973-1976.

Väestönmuutokset vuonna 1970. (Vital Statistics 1970). SVT VIA: 132 - Official Statistics of Finland VI A: 132. Helsinki 1973, $100 \mathrm{pp}$.

- 1971, 1975, SVT VI A: 133, 88 pp.

- 1972, 1975 SVT VI A: 135,88 pp.

- 1973, 1976 SVT VI A: 136, 92 pp.

Yleinen väestönlaskenta Helsingissä vuonna 1970. (Population census in Helsinki 1970). Helsingin kaupungin tilasto. Erikoistutkimukset VII: 8 - Statistics of the City of Helsinki, Special investigations, Helsinki 1974.

Yleinen väestölaskenta Turussa 1970. (Population census in Turku 1970). Turun kaupungin tilastotoimiston tiedotuksia 1/1976. Turku 1976, $182 \mathrm{pp}$. 
Aaltonen, Matti - P

Aarnio, Aulis - M

Alanen, Leena - B

Allardt, Erik - J, P

Allefresde, Maurice - P

Amnell, Gustav - E

Apajalahti, Jouni - P

Asp, Erkki - B

Auvinen, Riitta - M

Bergman, Turo - H, P

von Bonsdorff, Göran - P

Broo, Roger - P

Brummer, Pekka - E

Brunström, K.J. - P

Edgren, Christian - H, P

Eriksson, Aldur W. - B, F

Filpus, Timo - M

Forsberg, Karl-Erik - B, C, D, F, P

Fougstedt, Gunnar - D, K, P

Frederiksen, Ilkka - B

Gustafsson, Mervi - $\mathrm{H}$

Haavio-Mannila, Elina - I, J, P

Hautamäki, Lauri - P

Heikkilä, Lena - J

Heikkinen, Sirkka-Liisa - H, P

Hemminski, E. - E

Hervă, Aslak - A, N

Hietala, Kari - I, J, K, P

Hoikkanen, Silja - J

Hulkko, Jouko - D, M

Hulkko, S. - E

Huotari, Voitto - B

Huuhtanen, A $-\mathrm{E}, \mathrm{P}$

Huuhtanen, Pekka - H, P

Hägen, Kerstin - P

Härkäpää, Markus - C

Hölttä, Irma - I

Inkinen, Irja - I

Jaakkola, Magdalena - P

Johansson, Sten - J

Jungar, Sune $-\mathrm{H}$

Jungner, Yngve - I

Juntunen, Esko - I

Justander, Kalle - P

Jutikkala, Eino - P

Jyrkilä, Faina - I

Järvenpää, Pentti - H

Järvenranta, Marjut - C

Järvikoski, Timo - B

Kajanoja, Jouko - P
Kallio, Hanna - F

Kamppinen, Arto - I

Karivalo, Merja - N

Karjalainen, Irma - D

Karjalainen, Pirkko - E

Karni, Michael - H

Kaukiainen, Y. - B

Kauppi, Hannu - P

Kaups, Matti - H

Kenttä, Aaro - D, P

Kero, Reino - $\mathrm{H}$

Kiiskinen, Auvo - M

Koiranen, Vilho - A, P

Koivukangas, Olavi - B, H, J, P

Koivukoski, Eero - P

Koivula, Samuli - A, K

Kolari, Risto - E

Korpelainen, Lauri - J, K, P

Korpinen, Pirkko - I

Korva, Timo - $\mathrm{P}$

Koskela, Lauri - N

Koskelainen, Osmo - F, N, P

Koski, Riitta - I

Koskiaho, Brita - L

Kosonen, Matti - I

Kotiranta, Marja-Liisa - F

Krokfors, Christer - A

Kulokari, Hannu - N

Kuokkanen, Aarne - C, J

Kåhre, Inga - $\mathrm{O}$

Laakso, Leo - J

Laaksonen, Pirjo - Q

Laaksonen, Seppo - N

Lahti, Raimo - F

Lahtinen, Yrjö $-J$

Lallukka, Seppo - L, M

Lankinen, Markku - B, K

Laukkanen, Pertti - K

Lehtonen, Kaarina - P

Leppo, Kimmo - A, F, L, M, N, P

Leppänen, Leena - I

Leveelahti, Ilkka - I, L, P

Lietsala, Leena - G

Lind, Jouko - $\mathrm{P}$

Lindgren, Jarl - F, K, L, M, P

Lipponen, Paavo - P

Lähderanta, Uolevi - E

Lähteinen, Martti - E

Majava, Altti - H, I, P

Manninen, Paavo - $\mathrm{K}$

Markelin, Pasi - A 
Matthiessen, P.C. - P

Mehtonen, Pentti - L

Meinander, Nils - P

Mikkola, Kimmo - B, H, I, P

Murros, H. - I

Mustonen, Irmeli - B, I

Mustonen, Maija - E

Myrskylä, Pekka - F, J, K, P

Mäenpää, Jalo - S

Narjus, Raimo - $\mathrm{P}$

Naukkarinen Arvo - I, N

Nevalainen, Risto - N

Nevanlinna, Harri R. - L

Niemi, Einar - H, I

Nieminen, Mauri - A, D, N

Nieminen, Seppo - I

Nykänen, Heikki - B, D

Ollila, Douglas J. - H

Orrman, Eljas - Q

Orta, Timo - H

Pajulahti, Lauri - C

Pentinmäki, Erkki - P

Pesonen, Jukka - B

Piepponen, Paavo - M

Piepponen, Risto - P

Pihlajarinne, Eero - I

Pirilä, Marja - Q

Puntala, Pentti - F

Purola, Tapani - K, P

Pääkkönen, Hemmi - P

Quick, Holger - $\mathrm{H}$

Railimo, Sirpa - K

Ranta, Tauno - P

Rantanen, Kari - B

Rapola, J. - E

Raivio, Yrjö - B, H

Rekola, Pekka - P

Relander, Timo - P

Riihinen, Olavi - J

Rikkinen, Kalevi - N

Rinne, Risto - M

Ripatti, Aku-Kimmo - P

Rissanen, Viljo - E

Ritamies, Marketta - G

Romppanen, Antti - O

Ruokonen, Merja - J
Salo, Mikko A. - N

Saloheimo, Veijo - I

Salmela, Arto - P

Salmela-Mattila, Juhani - P

Sarin, Mirja - B

Savaspuro, T. - B

Savela, Veikko - O, P

Savisalo, U. - I

Saxen, Ake - E

Seppänen, Jaakko - D, K

Sievers, Kai - F, N, P

Sihvo, Jouko - G

Similä, P. - I

Sippola, Matti - A, P

Sipponen, Kauko - M, P

Soininen, Veli - M

Suominen, Leena - M

Suominen, Risto - E, M

Suonoja, Kyösti - E

Stolte-Heiskanen, Veronica - M

Strömmer, Aarno - A, P

Tainio, Risto - K

Talvitie, Juha - P

Tapio, Markku - H, P

Tattari, Veikko - P

Tauriainen, Juhani - A, G, P

Tikkanen, Anja - B

Tissari, Jukka - H

Toivonen, Timo - J

Toukomaa, Pertti - B

Träsk, Inger - $\mathrm{K}$

Tukiainen-Pankakoski, Tuuli - C

Tuomaala, Juhani - P

Tuomiharju, Tapani $-\mathrm{H}$

Turpeinen, Oiva - E, F, N

Vaisto, Erkki - Q

Valkonen, Tapani - A, B, E

Walls, Georg - H

Wickström, Johan - B

Widen, Bill - H

Wiman, Ronald - H, I, K, L, P

Visuri, Elina - G, P

Witthaur, K. - B

Åikäs, Timo - E

Ylppö, Arvo - F

Ylärakkola, Arvo - I 